\title{
PENGARUH ORIENTASI DAN EDUKASI KEWIRAUSAHAAN TERHADAP KINERJA FINANSIAL BISNIS UMKM DI KOTA BOGOR
}

\author{
Erland Adrian dan Andi Wijaya \\ Program Studi Manajemen Fakultas Ekonomi, Universitas Tarumanagara, Jakarta \\ Email : Erland13adrian@gmail.com
}

\begin{abstract}
The purpose of this research is (1) To study the Entrepreneurship Orientation research on the Financial Performance of MSME Businesses in the City of Bogor. (2) To determine the effect of Entrepreneurship Education on Financial Performance of MSME Businesses in the City of Bogor. The sample was selected using a quantitative method chosen by 80 respondents who owned an MSME business in Bogor City. The results show a positive and significant commitment to financial business on business performance and entrepreneurship education supporting a positive and significant impact on MSME business performance in Bogor City.
\end{abstract}

Key word: Entrepreneurial Orientation, Entrepreneurial Education, Financial Business Performance.

Abstak: Tujuan dari penelitian ini adalah (1) Untuk mengetahui pengaruh dari Orientasi Kewirausahaan terhadap Kinerja Finansial Bisnis UMKM di Kota Bogor. (2) Untuk mengetahui pengaruh dari Edukasi Kewirausahaan terhadap Kinerja Finansial Bisnis UMKM di Kota Bogor. Sampel dipilih menggunakan metode kuantitatif berjumlah 80 responden pemiliki usaha UMKM di Kota Bogor. Hasil menunjukan orientasi kewirausahaan secara langsung berpengaruh positif dan signifikan terhadap kinerja finansial bisnis dan edukasi kewirausahaan berpengaruh positif dan signifikan terhadap kinerja finansial bisnis UMKM di Kota Bogor.

Kata kunci : Orientasi Kewirausahan, Edukasi Kewirausahaan, Kinerja Finansial Bisnis.

\section{LATAR BELAKANG}

Di dunia ada banyak negara dan negara-negara tersebut bisa terbagi menjadi negara maju atau negara berkembang. Negara maju adalah sebutan untuk negara yang mempunyai standar hidup yang relative tinggi melalui teknologi tinggi dan ekonomi yang merata. Contohnya negara maju adalah Amerika Serikat, Belanda, China, Spanyol, Portugal dan masih banyak lagi. Sedangkan negara berkembang adalah sebuah negara dengan rata- rata pendapatan yang rendah, infrastruktur yang relative terbelakang dan indek perkembangan manusia yang kurang dibandingkan dengan norma global. Contoh negara berkembang adalah Meksiko, India, Indonesia dan lain-lain. Indonesia telah dikenal sebagai negara yang berkembang dengan pertumbuhan ekonomi yang sangat stabil dan keragaman sosial budaya yang sangat besar. 
Usaha mikro, kecil dan menengah (UMKM) merupakan pelaku bisnis yang bergerak pada berbagai bidang usaha, yang menyentuh kepentingan masyarakat. Dalam proses pemuliha ekonomi Indonesia, sektor UMKM memiliki peranan yang sangat stategis dan penting yang dapat ditinjau dari berbagai aspek. Salah satu upaya peningkatan dan pengembangan UMKM dalam perekonomian nasional dilakukan dengan mendorong intensitas kewirausahaan kepada para pelaku UMKM. UMKM sebagai Usaha Mikro Kecil dan Menengah, dewasa ini mendapatkan perhatian yang besar dari pemerintah karena kontribusinya yangsangat besar terhadap upaya untuk meningkatkan taraf hidup rakyat karena secara umum keberadaan Usaha Mikro Kecil dan Menengah (UMKM) di negaranegara berkembang dapat dikatakan sebagai tulang punggung perekonomian negara. Keberadaan UMKM terbukti telah mampu menggerakkan roda perekonomian bangsa dan mengurangi jumlah pengangguran yang ada. Berdasarkan fenomena di atas, model potensi perluasan kerja untuk mengatasi pengangguran dan kemiskinan perlu dikembangkan melalui penciptaan kesempatan kerja langsung dalam bentuk kerja mandiri, usaha keluarga, atau usaha kecil. Perkembangan dan kontribusi UMKM dalam perekonomian Indonesia tidak dapat diragukan lagi. Jumlah UMKM dan sumbangan Produk Domestik Bruto (PDB) UMKM di Indonesia dari tahun ke tahun selalu mengalami peningkatan. Eksistensi dan peran UMKM pada tahun 2013 mencapai 57,8 juta unit usaha. Kontribusi UMKM dalam pembentukan PDB Nasional selalu meningkat sampai dengan tahun 2013 sebesar Rp 1.536.918,8 Miliar (Kementerian Koperasi dan UKM Republik Indonesia).

Dari waktu ke waktu perusahaan diharapkan agar mengembangkan keterampilan. Misalnya; kemampuan untuk mengelola resiko, kemampuan untuk berinovasi untuk memenuhi kebutuhan, munculnya peluang dan ancaman, kemampuan untuk mengantisipasi arah dan sifat perubahan pasar dan kemampuan untuk mentoleransi resiko. Sehingga perusahaan akan semakin terpacu untuk lebih meningkatkan kinerja bisnisnya. Sejalan dengan penelitian yang telah ada sebelumnya, diharapkan bahwa ketiga dimensi Orientasi Kewirausahaan, dapat berpengaruh positif terkait dengan kinerja bisnis. (Covin et al, 2006; Rauch et al, 2009). Dengan ini dapat dikatakan bahwa Orientasi Kewirausahaan memiliki keterkaitan dengan kinerja bisnis suatu perusahaan. Terutama dalam hal pengevaluasian kinerja seuah perusahaan, dengan harapan perusahaan dapat menuju ke arah perkembangan yang positif.

\section{KAJIAN TEORI}

Orientasi kewirausahaan sebagai kombinasi perilaku inovatif, proaktif dan pengambilan risiko yang dimaksudkan untuk menciptakan nilai dalam organisasi. Suatu organisasi dapat memiliki struktur kewirausahaan, dan anggota suatu organisasi bisa berwirausaha, dan masingmasing saling melengkapi untuk memberikan sinergi.

Edukasi kewirausahaan berfokus pada pengembangan pengetahuan wirausaha, kapasitas, keterampilan, serta sikap dan niat wirausaha yang sesuai dengan kebutuhan ekonomi.

Kinerja bisnis dapat didefinisikan sebagai seberapa besar suatu organisasi dapat mengatasi fluktuasi faktor lingkungan hidup bisnis. Dalam penelitian empiris tentang kinerja bisnis, beragam langkah telah digunakan. Secara umum, kinerja bisnis dapat diklasifikasikan dalam dua kategori, kinerja keuangan dan kinerja non-keuangan. Kinerja bisnis keuangan biasanya mencakup ukuran pertumbuhan dan ukuran profitabilitas dan kinerja bisnis nonfinansial mencakup tingkat pertumbuhan karyawan, tanggung jawab sosial, kemampuan pembelajaran organisasi dan potensi pertumbuhan 


\section{Orientasi Kewirausahaan}

Orientasi Kewirausahaan adalah Perkembangan dalam bidang manajemen strategik mengalami pergeseran pada proses kewirausahaan, yang mana metode, praktik, dan gaya pengambilan keputusan manager menggunakan tindakan kewirausahaan (Lumpkin \& Dess, 1996).

\section{Edukasi Kewirausahaan}

Edukasi Kewirausahaan merupakan upaya menginternalisasikan jiwa dan mental kewirausahaan baik melalui institusi pendidikan maupun institusi lain seperti lembaga pelatihan, training dan sebagainya (Wahyidiono, 2016).

\section{Kinerja Finansial Bisnis}

Kinerja Finansial Bisnis adalah prestasi yang dicapai oleh suatu perusahaan pada periode tertentu yang mencerminkan tingkat kesehatan perusahaan tersebut (Sutrisno, 2009).

\section{Kaitan antara Orientasi Kewirausahaan dan Kinerja Finansial Bisnis}

Dengan begitu dapat diketahui bahwa orientasi kewirausahaan berpengaruh kepada kinerja finansial bisnis karena orientasi kewirausahaan memberikan suatu kontribusi terhadap kinerja yang didefinisikan sebagai "sebuah ukuran majemuk", yang mencakup dimensi pertumbuhan dan juga kinerja keuangan sehinggan adanya keberanian untuk mengambil resiko, inovasi dan sikap proaktif akan membuah sebuah usaha mampu mensejajarkan dengan pesaing mereka dan kinerja sebuah usaha dapat dilihat dari kepuasan pelanggan, loyalitas, pertumbuhan penjualan dan profitabilitas.

H1 : Orientasi Kewirausahaan berpengaruh positif dan signifikan terhadap Kinerja Finansial Bisnis UMKM di Kota Bogor.

\section{Kaitan antara Edukasi Kewirausahaan dan Kinerja Finansial Bisnis}

Dengan begitu dapat diketahui bahwa edukasi kewirausahaan berpengaruh signifikan terhadap kinerja finansial bisnis karena seseorang yang menjalankan suatu usaha membutuhkan jiwa kewirausahaan yang dapat mengelola bisnis dengan baik hingga mendapat laba yang besar, maka dari itu dibutuhkan kreativitas didalam suatu usaha atau bisnis agar dapat bersaing di bidang usahanya, dari hal tersebut dapat dilihat bahwa kreativitas dapat didapatkan dari edukasi kewirausahaa.

H2 : Edukasi kewirausahaan berpengaruh positif dan signifikan terhadap Kinerja Finansial Bisnis UMKM di Kota Bogor.

Berdasarkan uraian kaitan antar variabel di atas, maka model penelitian yang digunakan dalam penelitian ini adalah sebagai berikut. 


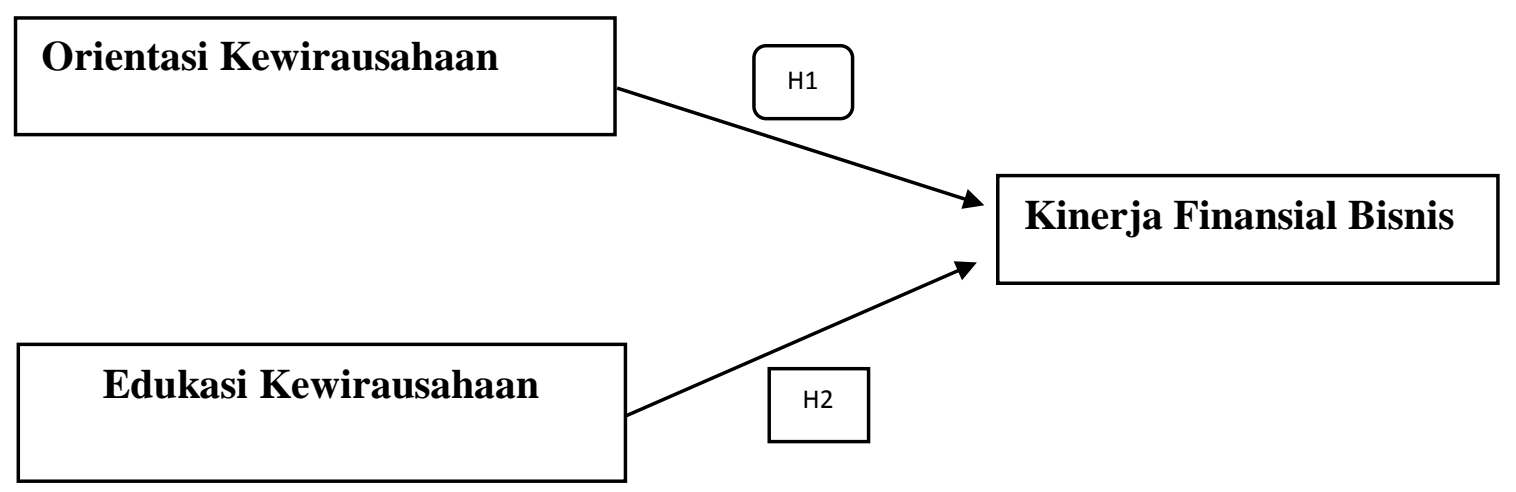

Gambar 1. Model Penelitian

\section{METODOLOGI}

Penelitian ini menggunakan desain penelitian deskriptif yang didesain untuk mengumpulkan data yang mendeskripsikan suatu karakteristik seseorang, aktivitas dan situasi. Penelitian ini menggunakan metode kolerasi atau korelasional adalah suatu penelitian untuk mengetahui hubungan dan tingkat hubungan antara dua variable atau lebih tanpa ada upaya untuk mempengaruhi variabel tersebut sehingga tidak terdapat manipulasi variabel. Dalam penelitian ini populasinya adalah pemilik usaha UMKM yang berdomisili di Kota Bogor.

Penelitian ini menggunakan non-probability sampling sebagai tehnik pemilihan sampel dimana setiap anggota populasi tidak memiliki kesempatan yang sama untuk dipilih menjadi sampel. Dalam penelitian ini, peneliti memilih dan mengambil sampel dengan menggunakan teknik judgmental sampling yang tujuanya agar pengumpulan data dapat dilakukan dengan mudah dan cepat. Penelitian ini menggunakan sampel sebanyak 100 sampel.

Pengukuran variabel-variabel dalam penelitian ini mengacu pada penelitian sebelumnya antara lain sebagai berikut:

\begin{tabular}{lll} 
Variabel & Indikator & Acuan \\
\hline Orientasi Kewirausahaan & 6 item & Buli, B. M (2017) \\
\hline Edukasi Kewirausahaan & 3 item & $\begin{array}{l}\text { Anggraeni, D dan } \\
\text { Nurcaya, I.(2016) }\end{array}$ \\
\hline Kinerja Finansial Bisnis & 3 item & $\begin{array}{l}\text { Radzi, et al } \\
(2017)\end{array}$
\end{tabular}

\section{Hasil Uji Statistik}

Analisis validitas, baik convergent validity maupun discriminant validity, telah dilakukan dengan menggunakan analisis average variance extracted, loading factors, dan cross loading. Hasilnya seluruh variabel dan indikator dalam penelitian ini valid untuk digunakan. Keempat variabel yang digunakan dalam penelitian ini juga dinyatakan reliabel, karena memiliki nilai composite reliability diatas 0,70 (malhotra, 2010) dan nilai cronbach's alpha diatas 0,60 (Hair et al, 2008).

$\mathrm{R}^{2}$ digunakan untuk mengukur seberapa besar variabel Orientasi Kewirausahaan dan Edukasi Kewirausahaan, menjelaskan variabel Kinerja Finansial Bisnis. $R$ square sebesar 0,724 menjelaskan bahwa sebesar 72,4\% dari variabel dependen yaitu Kinerja Finansial Bisnis 
dapat dijelaskan oleh variabel-variabel yang diteliti pada penelitian ini, sisanya sebesar 27,6\% dapat dijelaskan oleh variabel-variabel lain yang tidak diteliti dalam penelitian ini. Berdasarkan hasil pengujian di atas dapat disimpulkan bahwa nilai $R$-Square dalam penelitian ini tergolong moderate (Hair et al., 2011). Selanjutnya, hasil pengujian $\mathrm{Q}^{2}$ menunjukan nilai sebesar 0,440 untuk variabel Kinerja Finansial Bisnis yang artinya nilai predictive relevance $\left(\mathrm{Q}^{2}\right)$ dalam penelitian ini lebih besar dari pada 0 .

Hasil analisis data secara singkat dapat dilihat pada Tabel 1.

\begin{tabular}{|c|c|c|c|}
\hline \multicolumn{4}{|c|}{$\begin{array}{c}\text { Tabel } 1 \\
\text { Hasil Pengujian Hipotesis }\end{array}$} \\
\hline Variabel & Original Sample & t-statistics & p-values \\
\hline $\begin{array}{l}\text { Orientasi Kewirausahaan -> Kinerja } \\
\text { Finansial Bisnis }\end{array}$ & 0,551 & 6,980 & 0.000 \\
\hline $\begin{array}{l}\text { Edukasi Kewirausahaan -> Kinerja } \\
\text { Finansial Bisnis }\end{array}$ & 0,393 & 4,331 & 0.000 \\
\hline
\end{tabular}

Hasil Pengujian hipotesis yang diperoleh untuk pengaruh orientasi kewirausahaan terhadap kinerja finansial bisnis dalam penelitian ini menghasilkan, nilai T- statistic sebesar 6,980, nilai P-value sebesar 0,000 dan dimana nilai t-statistic lebih besar dari 1,96 dan nilai pvalue yang berada dibawah 5\%. Dari pengujian diatas dapat disimpulkan bahwa orientasi kewirausahaan berpengaruh positif dan signifikan terhadap kinerja finansial bisnis UMKM di Kota Bogor.

Hasil Pengujian hipotesis yang diperoleh untuk pengaruh edukasi kewirausahaan terhadap kinerja finansial bisnis nilai T-statistic sebesar 4,331 dan nilai P-value sebesar 0,000. Dimana nilai T-statistic perkembangan ekonomi kewirausahaan lebih besar dari 1,96 dan juga nilai P-value yang lebih kecil dari 5\%. Dari data pengujian diatas maka dapat disimpulkan bahwa terdapat pengaruh signifikan perkembangan ekonomi kewirausahaan terhadap wirausahawan perempuan di Kota Bogor.

Pengujian Goodness of fit (GoF) untuk menggambarkan seberapa besar nilai variable dependen dapat memprediksi keseluruh model. Hasil perhitungan menunjukan hasil yang menyatakan model yang digunakan dalam penelitian ini memiliki nilai GoF sebesar 0,684. Menurut Ghozali (2014), menjelaskan bahwa uji GoF Digunakan untuk memvalidasi performa gabungan antara model pengukur (outer model) dan model struktural (inner model) yang nilainya terbentang antara 0-1 dengan interpretasi yaitu 0-0,25 (GoF kecil), 0,25-0,36 (GoF moderat), dan diatas 0,36 (GoF besar). GoF index dapat dihitung dari akar kuadrat nilai Average Communality Index dan average $R$-square.

\section{DISKUSI}

Nilai original sample pada variable orientasi kewirausahaan (X1) sebesar 0,551 menjelaskan bahwa terdapat pengaruh positif orientasi kewirausahaan terhadap kinerja finansial bisnis dan nilai t-statistik yang diperoleh sebesar 6,980 dimana nilai tersebut lebih besar dari nilai t-table $>1,96$ serta nilai pada -value yaitu sebesar 0,000 yang artinya nilai tersebeut lebih kecil dibandingkan dengan t-table yang telah ditetapkan dengan nilai sebesar 
0,05. Dengan demikian dapat disimpulkan bahwa terdapat pengaruh positif dan signifikan orientasi kewirausahaan terhadap kinerja finansial bisnis sehingga $\mathrm{H} 1$ diterima.

Nilai original sample pada variabel edukasi kewirausahaan (X2) sebesar 0,393 menjelaskan bahwa terdapat pengaruh positif edukasi kewirausahaan terhadap kinerja finansial bisnis dan nilai t-statistik yang diperoleh sebesar 4,331 dimana nilai tersebut lebih besar dari nilai t-table $>1,96$ serta nilai pada $\mathrm{p}$-value yaitu sebesar 0,000 yang artinya nilai tersebut lebih kecil dibandingkan dengan t-table yang telah ditetapkan dengan nilai sebesar 0,05. Dengan demikian dapat disimpulkan bahwa terdapat pengaruh positif dan signifikan edukasi kewirausahaan terhadap kinerja finansial bisnis sehingga $\mathrm{H} 2$ diterima.

\section{PENUTUP}

Berdasarkan hasil pengujian data dalam penelitian ini, menghasilkan dua jawaban yang pertama yaitu terdapat pengaruh yang positif dan siginifikan orientasi kewirausahaan terhadap kinerja finansial bisnis UMKM di Kota Bogor dan yang kedua terdapat perngaruh yang positif dan signifikan edukasi kewirausahaan terhadap kinerja finansial bisnis UMKM di Kota Bogor. Pada penelitian ini terdapat beberapa keterbatasan: (1) penelitian ini hanya menggunakan sampel sebanyak 80 responden, (2) Populasi penelitian ini terbatas hanya pemilik usaha UMKM di Kota Bogor saja sehingga pengambilan sampel kurang meluas. Berdasarkan hasil dari penelitian tersebut, maka saran untuk penelitian selanjutnya dapat meneliti dengan variabel yang berbeda dengan variabel yang telah digunakan pada penelitian ini, dengan menggantikan variabel lain maka nantinya akan lebih luas lagi cakupan data yang diteliti sehingga mampu mendapatkan data yang diinginkan.

\section{DAFTAR PUSTAKA}

Anggraeni D., Nurcaya I. (2016). Peran Efikasi Diri Dalam Memediasi Pengaruh Pendidikan Kewirausahaan Terhadap Niat Berwirausaha.

Buli, B. M. (2017). Entrepreneurial Orientation, Market Orientation and Perfomance of SMEs in the Manufacturing Industry: Evidence from Ethiopian Enterprises. Management Research Review, 40(3), 1-23.

Ghozali, I. (2014). Structural equation modeling: metode alternative dengan Partial Least Square (PLS). Semarang : Badan Penerbit Universitas Diponegoro.

Hair, J. F. Jr., Anderson, R. E., Tatham, R. L. and Black, W. C. (2008). Multivariate Data Analysis. New Jersey: Prentice-Hall

Hair, J. F. Jr., Anderson, R. E., Tatham, R. L., Black, W. C., Ringle, C. M., \& Sarstedt, M. (2011) PLS-SEM: Indeed A Silver Bullet. The Journal of Marketing theory and Practice, 19(2), 139-152.

Lumpkin, g t., and Dess, g. g. (1996). Clarifying The Entrepreneurial Orientation Construct and Linking it to Performance. academy of management review, 21(1): 135-172.

Radzi, K., Nor, M dan Ali, S (2017). EBSCOhost |124582513| The impact of internal factors on small business success : A case of small enterprises under the FELDA Scheme, vol 22, no 1, 25-55. 
Sutrisno. (2009), Manajemen Keuangan Teori, Konsep dan Aplikasi, Edisi Pertama, Cetakan Ketujuh, Penerbit Ekonisia, Yogyakarta.

Wahyudiono, 2016. Pengaruh Pendidikan Kewirausahaan, Pengalaman Berwirausaha, dan Jenis Kelamin terhadap Sikap Berwirausaha pada Mahasiswa Fakultas Ekonomi Universitas Muhammadiyah Surabaya, Jurnal Ekonomi Pendidikan dan Kewirausahaan, Vol. 4. No. 1. Hal. 76-91. 